\title{
CORRESPONDENCE
}

\section{BAILLIART'S DYNAMOMETER}

To the Editors of THE BRITISH JoURnAL OF OPHTHALMOLOGY.

DEAR SIRS,-May I congratulate Mr. Foster on his valuable description of the continental clinics, but on one point only I disagree. I have used Bailliart's dynamometer for over fifteen years and $I$ find this a reliable and important method in measuring the arterial tension in different branches of the vascular tree. The method is not easy, but once mastered is as precise as measuring of the blood pressure by a sphygmomanometer. I am usually satisfied with an approximate measurement without taking the intraocular pressure as well.

$$
\begin{aligned}
& \text { I am, Sir, } \\
& \text { Your obedient Servant, }
\end{aligned}
$$

\section{1, PHILPOT STREET, E. 1.}

N. Pines.

April 16, 1948.

\section{OBITUARY}

\author{
H. SECKER WALKER, F.R.C.S. \\ Ophthalmic Surgeon, The General Infirmary at Leeds. \\ April, 1863 - February, 1948.
}

BORN in 1863, the second son of Dr. Thomas Walker of Wakefield, Secker Walker was educated at the Grammar School of that city, and at University College Hospital, London.

Shortly after his appointment as Hon. Asst. Surgeon to the Eye, Ear, Nose and Throat Department of the General Infirmary at Leeds in 1890, he spent six months in Vienna, and after returning was one of the first Englishmen to perform a mastoidectomy.

From 1912, on the division of Ophthalmic and Aural Departments at the Infirmary, he confined his practice to ophthalmic surgery.

In 1914, H.H. The Jam Sahib of Nawanagar (the immortal Ranji) became his patient, after a serious grouse-shooting accident, and in gratitude for his recovery, in addition to naming a ward after. Secker Walker in Nawanagar Hospital, " Ranji " provided the Leeds Infirmary with a new, ophthalmic theatre, and out-patient department. The design of these incorporated many of Secker Walker's own ideas. 